\title{
Isoenzyme activity in maize hybrid seeds harvested with different moisture contents and treated ${ }^{1}$
}

\author{
Thaís Francielle Ferreira ${ }^{2 *}$, Valquíria de Fátima Ferreira², João Almir Oliveira ${ }^{2}$, \\ Marcos Vinícios de Carvalho², Leonardo de Souza Miguel ${ }^{2}$
}

\begin{abstract}
The analysis of isoenzyme activity is an important monitoring and characterization tool of the physiological quality of seeds and to understand the deterioration. The purpose of this work was to study the isoenzyme expression allied to the quality of maize hybrid seeds harvested at different moisture levels and subjected to chemical treatment. A completely randomized experimental design was used with four replicates, in a $3 \times 2$ factorial arrangement with three moisture levels (45\%, 40\% and 35\%), and two forms of seeds tillage (with and without treatment). Seeds from maize hybrids, semi-hard BM 810 and dented BM 3061, were used. Seeds were manually gathered on ears. Chemical treatment was performed with commercial products Maxin ${ }^{\circledR}+\mathrm{K}_{\text {-obiol }}{ }^{\mathbb{B}}$ + Actellic $^{\circledR}$. Seed quality was assessed by moisture test, incidence of mechanicals damage, first count of germination, germination, emergence, emergence speed index, mean emergence time, accelerated aging, and electrical conductivity. Isoenzyme expressions were assessed by means of the systems superoxide dismutase (SOD), catalase (CAT), esterase (EST), alcohol dehydrogenase (ADH), malate dehydrogenase (MDH), peroxidase (PO) and $\alpha$-amilase. Isoenzyme expressions are different, depending on moisture levels at harvest, the hybrid maize and seeds quality. Seeds treatment does not interfere in their isoenzymes expression.
\end{abstract}

Index terms: Zea mays, isoenzyme expression, physiological quality.

\section{Atividade isoenzimática em sementes de milho híbridos colhidas com diferentes teores de água e tratadas}

\begin{abstract}
RESUMO - A análise da atividade enzimática é uma importante ferramenta no monitoramento e caracterização da qualidade fisiológica de sementes e no entendimento da deterioração. Objetivou-se com este trabalho estudar a expressão de isoenzimas aliada a qualidade de sementes de milho híbrido colhidas com diferentes teores de água e submetidas ao tratamento químico. $\mathrm{O}$ delineamento utilizado foi o inteiramente casualizado, com quatro repetições, em esquema fatorial $3 \times 2$, sendo três teores de água (45\%, 40\% e 35\%), e duas formas de manejo das sementes (tratadas e não tratadas). Foram utilizadas sementes de milho dos híbridos: BM 810, semiduro e BM 3061, dentado, colhidas manualmente em espigas. O tratamento químico foi realizado com os produtos comerciais Maxin $^{\circledR}+\mathrm{K}^{-o b i o l}{ }^{\circledR}+$ Actellic $^{\circledR}$. A qualidade das sementes foi avaliada pelos testes de umidade, incidência de danos mecânicos, primeira contagem de germinação, germinação, emergência, índice de velocidade de emergência, tempo médio de emergência, envelhecimento acelerado e condutividade elétrica. As expressões isoenzimáticas foram avaliadas por meio dos sistemas superóxido dismutase (SOD), catalase (CAT), esterase (EST), álcool desidrogenase (ADH), malato desidrogenase $(\mathrm{MDH})$, peroxidase (PO) e $\alpha$-amilase. A expressão de isoenzimas é divergente dependendo do teor de água na colheita, do híbrido e da qualidade das sementes. $\mathrm{O}$ tratamento de sementes não interfere na expressão das isoenzimas.
\end{abstract}

Termos para indexação: Zea mays, expressão isoenzimática, qualidade fisiológica.

\section{Introduction}

The companies producing maize seeds every year have improved the cultivation system to obtain high quality seeds. This search triggers a high investment in technologies that enable a better use of time in relation to early harvesting.
The early harvest of maize seeds ensures higher quality due to less exposure to adverse environmental conditions, better use of planting areas, the possibility to vacate them earlier, besides enabling the planning of the drying processes, providing better utilization of the production and processing infrastructure (Ferreira et al., 2013).

\footnotetext{
${ }^{1}$ Submitted on $03 / 14 / 2015$. Accepted for publication on $05 / 30 / 2015$.

${ }^{2}$ Departamento de Agricultura, UFLA, Caixa Postal 3037, 37200-000 - Lavras, MG, Brasil.

* Corresponding author <franthata@yahoo.com.br>
} 
However, the seeds harvested close to physiological maturity, a period during which the seeds have maximum vigor level, show high water content and this involves the improvement of postharvest techniques so that there is not a reduction in seeds quality for, on a molecular level, a number of mechanisms contribute to the deterioration.

The enzymes involved in the deterioration, such as esterase (EST), malate dehydrogenase (MDH), alcohol dehydrogenase $(\mathrm{ADH})$, catalase (CAT) and peroxidase (PO) have great potential as molecular markers to monitor and characterize the seeds physiological quality (Veiga et al., 2010), besides providing an understanding of the causes of reduced vigor and viability (Galvão et al., 2014).

The delayed harvest leads to increased decay, and this is evident by the reduction of the peroxidase enzyme activity, which provides antioxidant protection of seeds (Tunes et al., 2014), and by the increased ADH enzyme activity, which increases anaerobic respiration (Caixeta et al., 2014).

Therefore, with the early harvest and the high moisture content of the seeds, there may be a significant increase in respiratory rate and deterioration if the processes subsequent to harvesting are not properly conducted (Galvão et al., 2014).

According to Caixeta et al. (2014), on seeds processed and stored for eight months, there is increased activity of the malate dehydrogenase enzyme, because the deteriorating process is steeper.

The loss of peroxidase enzyme activity due to increased deterioration can make seeds more sensitive to the effect of oxygen and free radicals on membrane unsaturated fatty acids, which will cause degeneration of these ones and compromise seed vigor (Martins et al., 2011).

The joint analysis of several enzyme systems enables the verification of changes that occur inside the seeds when subjected to some kind of treatment that influences quality and productivity (Tunes et al., 2014).

Studies of isoenzyme expression in maize seeds harvested with different moisture contents and changes in enzyme activity due to seeds chemical treatment are scarce. Thus, the aim of this research was to study the activity of isoenzymes superoxide dismutase (SOD), catalase (CAT), esterase (EST), alcohol dehydrogenase (ADH), malate dehydrogenase (MDH), peroxidase (PO) and $\alpha$-amylase at the expense of the hybrid maize seed quality, treated and untreated, harvested with different moisture contents.

\section{Material and Methods}

Hybrid seeds used were BM 810 and BM 3061, classified as semi-hard and toothed, produced by the company Biomatrix in the city of Paracatu, located North-West of the Brazilian state of Minas Gerais, whose geodetic coordinates are $17^{\circ} 13^{\prime} 19^{\prime \prime} \mathrm{S}$ of latitude, $46^{\circ} 52^{\prime} 30^{\prime \prime} \mathrm{W}$ of longitude and 1,008 meters of altitude.

At random points in the defined experimental area, manual harvesting of maize ears was done when the seeds had $45 \%$, $40 \%$ and $35 \%$ water content. The multi-grain apparatus Grain Analysis Computer 2100 was used to ascertain the moisture of the seeds. After harvest, the maize ears went through mechanical grain husking in machine to take the stover of the brand CWA in the rotation of $312 \mathrm{rpm}$ and drying in a stationary dryer at $35{ }^{\circ} \mathrm{C}$ until the seeds reached $22 \%$ water content and $42{ }^{\circ} \mathrm{C}$ until they reached $12 \%$ water content. After drying, the seeds were mechanically threshed and treated with Maxim $^{\circledR}+$ K-obiol $^{\circledR}+$ Actellic $^{\circledR}$, being $13.75 \mathrm{~mL}$ of Maxim $\mathrm{XL}, 0.45 \mathrm{~mL}$ of K-obiol, $0.45 \mathrm{~mL}$ of Actellic, $2.5 \mathrm{~mL}$ of dye, $100 \mathrm{~mL}$ of water (turned to $100 \mathrm{Kg}$ ). The treatments are specified in Table 1.

Table 1. Description of the treatments obtained by the different moisture contents at the time of harvest of maize (45\%, $40 \%$ and 35\%) with and without chemical treatment (T and UT), hybrids 1 and 2, water content (WC) .

\begin{tabular}{|c|c|c|c|c|}
\hline Treatments obtained & Hybrid & Harvest moisture (M) & Treatment Chemical & $(\mathrm{WC} \%)$ \\
\hline 1 & BM 810 & $45 \%$ & $\mathrm{~T}$ & 9.7 \\
\hline 2 & BM 810 & $40 \%$ & $\mathrm{~T}$ & 10.5 \\
\hline 3 & BM 810 & $35 \%$ & $\mathrm{~T}$ & 11.3 \\
\hline 4 & BM 810 & $45 \%$ & UT & 9.1 \\
\hline 5 & BM 810 & $40 \%$ & UT & 10.5 \\
\hline 6 & BM 810 & $35 \%$ & UT & 11.1 \\
\hline 7 & BM 3061 & $45 \%$ & $\mathrm{~T}$ & 9.7 \\
\hline 8 & BM 3061 & $40 \%$ & $\mathrm{~T}$ & 10.1 \\
\hline 9 & BM 3061 & $35 \%$ & $\mathrm{~T}$ & 10.1 \\
\hline 10 & BM 3061 & $45 \%$ & UT & 10.2 \\
\hline 11 & BM 3061 & $40 \%$ & UT & 10.4 \\
\hline 12 & BM 3061 & $35 \%$ & UT & 10.1 \\
\hline
\end{tabular}

Journal of Seed Science, v.37, n.2, p.139-146, 2015 
The seeds were submitted to manual classification in sieves at Central Laboratory of Seeds of the Department of Agriculture of the Federal University of Lavras, MG, Brazil. For hybrid BM 810, the seeds used were the ones retained in the oblong sieve 18/64 and for hybrid BM 3061, the ones retained in the circular sieve 20/64, and these sieves were selected due to the higher amount of retained seeds.

The determinations performed for the assessment of the seeds quality were: Moisture content, done by the oven method, described in the Rules for Seed Testing, with results expressed as mean percentage per treatment (Table 1) (Brasil, 2009); Incidence of mechanical damage, where seeds were immersed in the dye solution amaranth $^{\circledR}$ at $0.1 \%$, for 2 minutes, then rinsed under running water and assessment according to the methodology described by Oliveira et al. (1998); Germination, according to Brasil (2009), using 50 seeds for each of the four replications and assessment held at the fourth (first count of germination) and on the seventh day after sowing, computing the percentage of normal seedlings; Accelerated aging, with the use of gerbox-type plastic boxes adapted with hanging aluminum screen - in each germination box were added $40 \mathrm{~mL}$ of water and a single layer of seeds on the entire screen. They were then kept in a B.O.D. (Biochemical Oxygen Demand)type germination chamber at $42{ }^{\circ} \mathrm{C}$ for 96 hours (MarcosFilho, 1999) and after this period, the seeds were submitted to the germination test; Seedling emergence: the seeds were sown in plastic trays containing soil + sand as substrate, in the $2: 1$ ratio, moistened to $60 \%$ of the holding capacity. The trays were kept in the chamber at the temperature of $25^{\circ} \mathrm{C}$ and a photoperiod of 12 hours, with daily assessments of emergence of normal seedlings and a final score at 14 days after sowing. The final emergence percentage ( $\% \mathrm{E})$, the mean emergence time (MET) and the emergence speed index (ESI) were considered (Maguire, 1962); Electrical conductivity: it was performed according to Vieira and Krzyzanowski (1999), with the aid of a conductivity meter Digimed CD-21 and the results expressed in $\mu \mathrm{S} . \mathrm{cm}^{-1} \cdot \mathrm{g}^{-1}$; for the seeds treated, the conductivity value was subtracted from the blank test without seeds, only with the treatment product diluted in water so as to exclude the interference of seed treatment products in the values obtained.

The enzyme activities were also analyzed: $\alpha$-amylase, catalase, esterase, peroxidase, superoxide dismutase, malate dehydrogenase and alcohol dehydrogenase. For each system were used two samples of 50 seeds from each treatment. The seeds were soaked in the presence of antioxidant PVP and liquid nitrogen and subsequently stored at $-86^{\circ} \mathrm{C}$. For the extraction of enzymes catalase, esterase, peroxidase, superoxide dismutase, malate dehydrogenase and alcohol dehydrogenase was used buffer Tris $\mathrm{HCl} 0.2 \mathrm{M} \mathrm{pH} 8.0+0.1 \%$ of $\beta$-mercaptoethanol at the ratio of $250 \mu \mathrm{L}$ per $100 \mathrm{mg}$ of seeds.

For the extraction of $\alpha$-amylase enzyme, the seeds were germinated on paper roll for a period of 70 hours. After this period, plumule and root seeds were discarded and the remainder was macerated in mortar on ice, in the presence of liquid nitrogen. For extraction, $200 \mathrm{mg}$ of the powder of germinated seeds were resuspended in $600 \mu \mathrm{L}$ of the extraction buffer (Tris- $\mathrm{HCl} 0.2 \mathrm{M}, \mathrm{pH} 8.0+0.4 \%$ of PVP). The material was homogenized in a stirrer and kept in a refrigerator overnight, followed by centrifugation at $16,000 \mathrm{x}$ $\mathrm{g}$ for 60 minutes at $4{ }^{\circ} \mathrm{C}$.

The electrophoretic technique was performed in polyacrylamide gels system at $7.5 \%$ (separating gel) and $4.5 \%$ (concentrating gel). For the system $\alpha$-amylase was added $0.5 \%$ of soluble starch in the polyacrylamide gel. The gel/electrode system used was Tris-glycine $\mathrm{pH}$ 8.9. $15 \mathrm{uL}$ of the sample supernatant were applied and the technique was conducted at $150 \mathrm{~V}$ for 4 hours.

Gels were developed for enzymes catalase, esterase, malate dehydrogenase, alcohol dehydrogenase, superoxide dismutase, peroxidase $\alpha$-amylase (Alfenas et al., 2006).

A completely randomized design was used in a $3 \times 2$ factorial arrangement, whose factors were the seed moisture content at harvest (45\%, $40 \%$ and 35\%), seed treatment (treated and untreated) with four replicates per treatment. The hybrids were analyzed separately. For the isoenzymes expression, visual analysis of the expression bands was performed.

To compare the averages, Tukey test at 5\% probability was used, by software Sisvar (Ferreira, 2011). For testing water content and enzymes, statistical analyses of the data were not performed.

\section{Results and Discussion}

In the physiological tests of first count of germination, germination, seedling emergence, emergence speed index and electrical conductivity there was significance only for the harvest moisture factor, i.e., the seed treatment did not interfere in the results of both hybrids. There was interaction of harvest moisture and seeds treatment only for the accelerated aging test of hybrids BM 810 and BM 3061.

For hybrid BM 810, the seeds that were harvested at $45 \%$ water content showed a higher percentage of mechanical damage, particularly those classified into more serious damage (grades 3 and 2) and the seeds harvested at 40\% and 35\% water content were classified undamaged (grade 0) (Figure 1).

The germination of the seeds harvested at $35 \%$ water content was lower than the germination of the seeds that 
were harvested at $40 \%$ and $45 \%$ water content. The vigor of the seeds harvested at $45 \%$ water content was higher than the vigor of the seeds harvested at $35 \%$ and $40 \%$ water content in the tests of first count of germination, seedling emergence and electrical conductivity. The emergence speed index was the same, regardless of the water content in which the seeds were harvested (Table 2). The vigor of the treated and untreated seeds assessed by the accelerated aging test was higher in seeds at $35 \%$ water content. For the seed harvested at $40 \%$ and $45 \%$ moisture content, the treatment showed better performance in the accelerated

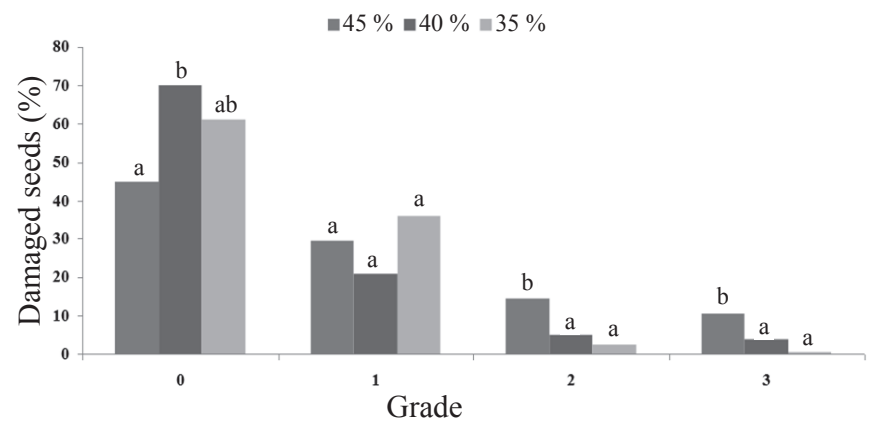

Figure 1. Incidence of mechanical damage in maize seeds hybrid BM 810 - semi-hard, harvested with different moisture contents $(45 \%, 40 \%$ and $35 \%)$ and classified into four levels $(0,1,2$ and 3$)$ in accordance with the intensity of the damage. Means followed by the same letter for each grade do not differ by Tukey test at $5 \%$ probability. aging test (Table 4).

The seeds of hybrid BM 3061 were more resistant to severe mechanical damage, although slight damage has been assessed (grade 1) (Figure 2). It is observed that the higher the water content of the seeds when harvested, the higher the incidence of damage considered serious (grade 3). The incidence of serious damage to seeds harvested at $35 \%$ and $40 \%$ water content did not differ. This high incidence of mechanical damage was caused above all by the steps of husking and threshing which, being mechanized, cause injuries in seeds.

Table 2. Average values of first count of germination (FC), germination $(\mathrm{G})$, emergence $(\mathrm{E})$, emergence speed index (ESI) and electrical conductivity (EC) of maize seeds hybrid BM 810, harvested with different moisture content $(\mathrm{M})$.

\begin{tabular}{cccccc}
\hline $\begin{array}{c}\mathrm{M} \\
(\%)\end{array}$ & $\begin{array}{c}\mathrm{FC} \\
(\%)\end{array}$ & $\begin{array}{c}\mathrm{G} \\
(\%)\end{array}$ & $\begin{array}{c}\mathrm{E} \\
(\%)\end{array}$ & ESI & $\begin{array}{c}\mathrm{EC} \\
\left(\mu \mathrm{S} \cdot \mathrm{cm}^{-1} \cdot \mathrm{g}^{-1}\right)\end{array}$ \\
\hline 35 & $98 \mathrm{a}$ & $89 \mathrm{~b}$ & $98 \mathrm{a}$ & $11.17 \mathrm{a}$ & $26.24 \mathrm{a}$ \\
40 & $96 \mathrm{a}$ & $97 \mathrm{a}$ & $97 \mathrm{ab}$ & $11.19 \mathrm{a}$ & $42.30 \mathrm{~b}$ \\
45 & $85 \mathrm{~b}$ & $98 \mathrm{a}$ & $92 \mathrm{~b}$ & $11.81 \mathrm{a}$ & $66.96 \mathrm{c}$ \\
\hline $\mathrm{CV}(\%)$ & 4.35 & 3.63 & 3.90 & 6.72 & 19.14 \\
\hline
\end{tabular}

Means followed by the same letter in the column do not differ by Tukey test at $5 \%$ probability.

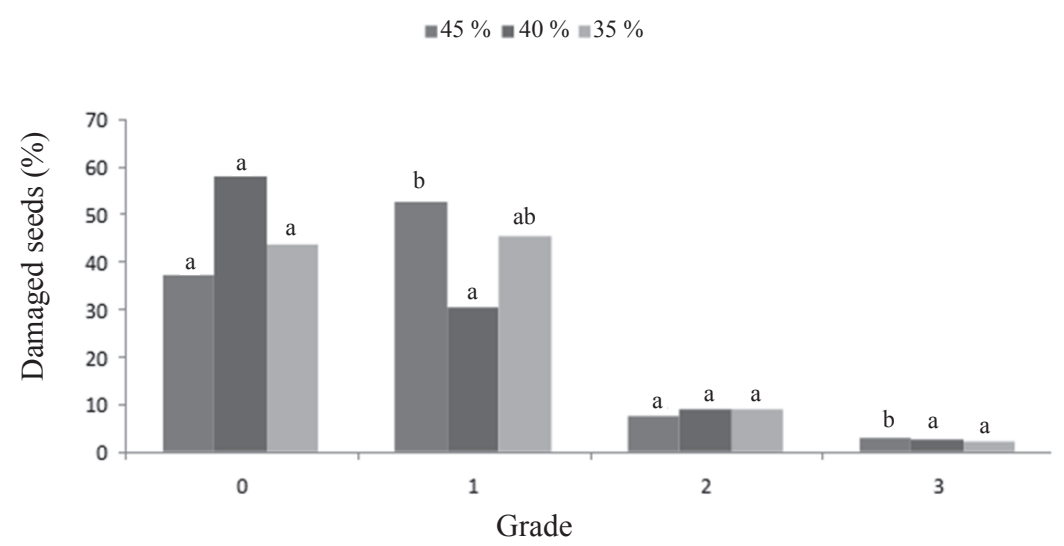

Figure 2. Incidence of mechanical damage in maize seeds hybrid BM 3061 - toothed, harvested with different moisture contents and classified into different grades. Means followed by the same letter for each grade do not differ by Tukey test at $5 \%$ probability.

The quality of the seeds harvested at $40 \%$ water content was higher than those harvested at $35 \%$ and $45 \%$ water content in the first count of germination, germination and emergence speed index. The electrical conductivity of the seeds at $45 \%$ water content was superior to others (Table 3). By the accelerated aging test, the vigor of treated seeds overcame the 
vigor of untreated seeds in seeds harvested at 35\% and $40 \%$ water content. In treated seeds, there was no vigor difference by the accelerated aging test, taking into consideration the water content in which the seeds were harvested (Table 4). The poor quality of seeds harvested at $45 \%$ water content is related to their susceptibility to mechanical damage during the husking and threshing mechanical processes. The damage caused in the seeds is a gateway to organisms that are harmful to quality and it is due to this fact that the vigor of untreated seeds was lower in the accelerated aging test when compared to the treated seeds

Table 3. Average values of first count of germination (FC), germination $(\mathrm{G})$, emergence $(\mathrm{E})$, emergence speed index (ESI) and electrical conductivity (EC) of maize seeds hybrid BM 3061, harvested with different moisture content (M).

\begin{tabular}{cccccc}
\hline $\begin{array}{c}\mathrm{M} \\
(\%)\end{array}$ & $\begin{array}{c}\mathrm{FC} \\
(\%)\end{array}$ & $\begin{array}{c}\mathrm{G} \\
(\%)\end{array}$ & $\begin{array}{c}\mathrm{E} \\
(\%)\end{array}$ & $\mathrm{ESI}$ & $\begin{array}{c}\mathrm{EC} \\
\left(\mu \mathrm{Sm}^{-1} \cdot \mathrm{g}^{-1}\right)\end{array}$ \\
\hline 35 & $98 \mathrm{ab}$ & $99 \mathrm{ab}$ & $99 \mathrm{a}$ & $11.77 \mathrm{ab}$ & $17.05 \mathrm{c}$ \\
40 & $100 \mathrm{a}$ & $100 \mathrm{a}$ & $100 \mathrm{a}$ & $12.13 \mathrm{a}$ & $20.78 \mathrm{~b}$ \\
45 & $96 \mathrm{~b}$ & $98 \mathrm{~b}$ & $98 \mathrm{a}$ & $11.73 \mathrm{~b}$ & $29.81 \mathrm{a}$ \\
\hline $\mathrm{CV}(\%)$ & 1.72 & 1.39 & 1.61 & 2.41 & 9.73
\end{tabular}

Means followed by the same letter in the column do not differ by the Tukey test at $5 \%$ probability.

Table 4. Mean values of normal seedlings germinated after accelerated aging of hybrid maize seeds, treated and untreated, harvested with different moisture content (M) for each hybrid.

\begin{tabular}{crrrr}
\hline \multirow{2}{*}{ M (\%) } & \multicolumn{2}{c}{ BM 810 } & \multicolumn{2}{c}{ BM 3061 } \\
\cline { 2 - 5 } & \multicolumn{1}{c}{ T } & UT & T & UT \\
\hline 35 & $100 \mathrm{aA}$ & $97 \mathrm{aA}$ & $98 \mathrm{aA}$ & $59 \mathrm{bB}$ \\
40 & $91 \mathrm{bA}$ & $81 \mathrm{bB}$ & $93 \mathrm{aA}$ & $83 \mathrm{aB}$ \\
45 & $84 \mathrm{bA}$ & $64 \mathrm{cB}$ & $94 \mathrm{aB}$ & $67 \mathrm{bA}$ \\
\hline $\mathrm{CV}(\%)$ & \multicolumn{2}{c}{4.56} & \multicolumn{2}{c}{10.20} \\
\hline
\end{tabular}

Means followed by the same lowercase letter in the column and uppercase letter on the row do not differ by Tukey test at $5 \%$ probability.

There was a higher intensity of the bands disclosed for enzymes superoxide dismutase (SOD) and catalase (CAT) in seeds of hybrid 1 (BM 810) when harvested at $45 \%$ water content. Unlike hybrid 2 (BM 3061), in which lower intensity of the bands of the enzymes in question was observed (Figure 3). The intensity of the bands disclosed for SOD was higher in BM 810 in the seeds harvested at $45 \%$ water content. There was a higher expression of enzyme catalase for these seeds that showed the highest incidence of mechanical damage and thus further deterioration, when compared with the ones at $40 \%$ and $35 \%$ water content.

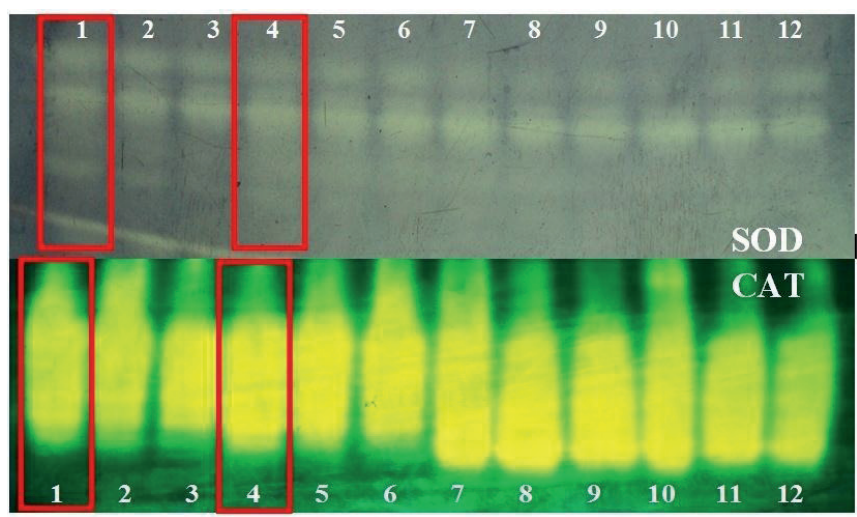

Figure 3. Enzymatic patterns of maize seeds harvested with different moisture contents $(45 \%, 40 \%$ and $35 \%)$ treated (T) and untreated (UT). Hybrid 1 - BM 810 $(1-45 \%$ T, $2-40 \%$ T, $3-35 \%$ T, $4-45 \%$ UT, $5-40 \%$ UT and $6-35 \%$ UT); Hybrid $2-$ BM 3061 (7-45\% T, $8-40 \%$ T, $9-35 \%$ T, $10-45 \%$ UT, $11-40 \%$ UT and $12-35 \%$ UT), disclosed for superoxide dismutase (SOD) and catalase (CAT).

With the increase of injuries in the seeds, the synthesis induction processes and activity of enzymes and hormones may be affected, reducing the activity of important enzymes in the respiratory process and removing free radicals, reducing the seeds physiological quality (Galvão et al., 2014). Marcos-Filho (2005) states that the increase of the enzyme catalase activity indicates the evolution of the deterioration due to the need for more intense action of the participating enzymes of the antioxidant complex.

These results corroborate the ones by Veiga et al. (2010) who stated that among the causes of decay events are changes in enzyme activity, which enable monitoring and characterizing the seeds quality.

It is observed in Figure 4 an increased expression of peroxidase enzyme in seeds harvested at $35 \%$ water content. The enzyme activity increases when the seeds water content is reduced to create protection mechanisms. Divergent results were found by Galvão et al. (2014), who observed that the delayed harvest reduced the peroxidase enzyme activity, indicating the occurrence of further deterioration of the seeds with the seeds delayed harvest.

The balance between the generation and removal of radicals during drying and storage of seeds, relates to its longevity (Martins et al., 2011), suggesting that the difference observed between the seeds harvested with different water content is related to the seeds age. 


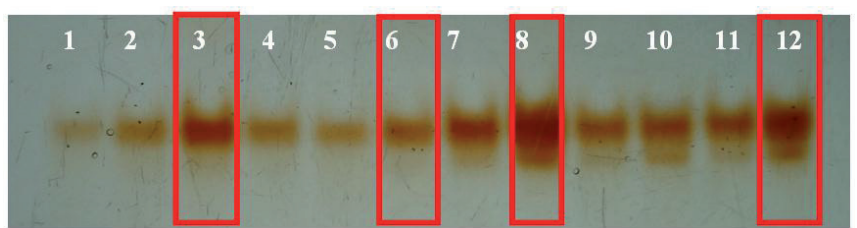

Figure 4. Enzymatic patterns of maize seeds harvested with different moisture contents $(45 \%, 40 \%$ and $35 \%)$ treated (T) and untreated (UT). Hybrid 1 - BM 810 (1 - 45\% T, $2-40 \%$ T, $3-35 \%$ T, $4-45 \%$ UT, $5-40 \%$ UT and $6-35 \%$ UT); Hybrid $2-$ BM $3061(7-45 \%$ T, $8-40 \%$ T, $9-35 \%$ T, $10-45 \%$ UT, $11-40 \%$ UT and $12-35 \%$ UT), disclosed for peroxidase.

The membrane systems of seeds harvested at $45 \%$ water content had a greater effect of exposure to oxygen due to the higher content of mechanical damage that they suffered during the process of husking, resulting in a lower expression of peroxidase enzyme, which can be also proven by the results of physiological tests where their poor performance is noted in both hybrids studied (Martins et al., 2011).

Most of the enzyme peroxidase activity in hybrid BM 3061 was observed when seeds were harvested at $40 \%$ water content and this may be related to their better quality and higher vigor, which can be proven by the germination tests and emergence speed index (Table 3 ).

In addition to protective enzymes, there are the deteriorative enzymes. Among them is esterase, which promotes hydrolysis of esters, where these reactions are directly related to the lipids metabolism. As an example, membrane phospholipids. Esterase promotes the destabilization of the lipid bilayer, accentuating the deterioration process (Vieira et al., 2006). Greater expression of this enzyme was observed in seeds harvested at $45 \%$ moisture content for both hybrids studied, which makes it clear that the seeds immaturity and the mechanical damage suffered during the processing and drying procedures contributed to the high activity of this enzyme (Figure 5).

For enzymes alcohol dehydrogenase $(\mathrm{ADH})$ and malate dehydrogenase $(\mathrm{MDH})$, there was a greater intensity of bands on seeds harvested at 45\% water content (Figure 6). The absence of oxygen promotes the beginning of the fermentation metabolism by induction of $\mathrm{ADH}$, wherein acetaldehyde is reduced to ethanol by nicotinamide adenine dinucleotide (NAD). According to Veiga et al. (2010) this enzyme is important since it converts acetaldehyde into ethanol, a compound with less toxicity, and reduces the speed of the deterioration process. Thus, the seeds are less susceptible to the deleterious effects of acetaldehyde with the highest activity of ADH (Carvalho et al., 2014).

It was observed that the changes occurring in the $\mathrm{ADH}$ enzyme activity seem to be due more to the mechanical damage that impairs the seeds metabolism, where higher enzyme activity was observed in both hybrids in the seeds harvested at $45 \%$ water content in both treated and untreated seeds.

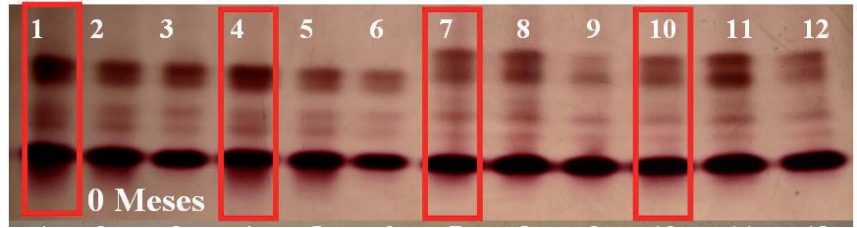

Figure 5. Enzymatic patterns of maize seeds harvested with different moisture contents $(45 \%, 40 \%$ and $35 \%$ ) treated (T) and untreated (UT). Hybrid 1 - BM $810(1-45 \%$ T, $2-40 \%$ T, $3-35 \%$ T, 4 $45 \%$ UT, $5-40 \%$ UT and $6-35 \%$ UT); Hybrid 2 - BM 3061 ( $7-45 \%$ T, $8-40 \%$ T, $9-35 \%$ T, $10-45 \%$ UT, $11-40 \%$ UT and $12-35 \%$ UT), disclosed for esterase.

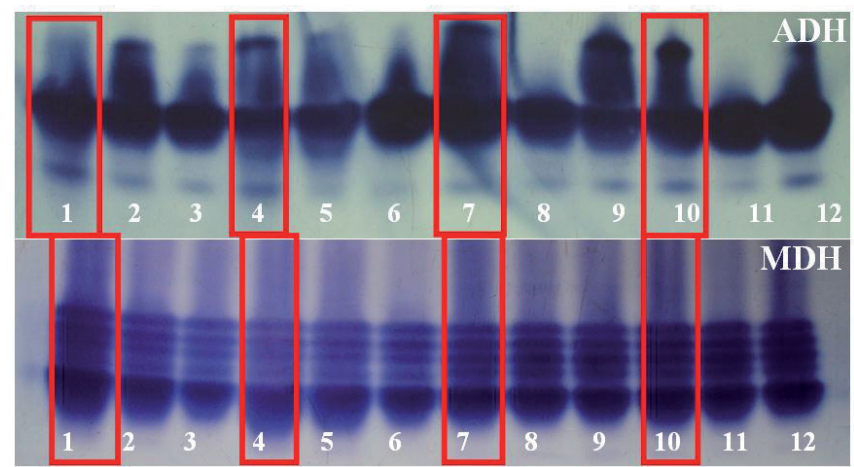

Figure 6. Enzymatic patterns of maize seeds harvested with different moisture contents $(45 \%, 40 \%$ and $35 \%)$ treated (T) and untreated (UT). Hybrid $1-\mathrm{BM}$ $810(1-45 \%$ T, $2-40 \%$ T, $3-35 \%$ T, $4-45 \%$ UT, 5- 40\% UT and $635 \%$ UT); Hybrid $2-$ BM $3061(7-45 \%$ T, $8-40 \%$ T, $9-35 \%$ T, $10-45 \%$ UT, $11-40 \%$ UT and $12-35 \%$ UT), disclosed for $\mathrm{ADH}$ - alcohol dehydrogenase and $\mathrm{MDH}$ - malate dehydrogenase.

Carvalho et al. (2014), when studying the expression of malate dehydrogenase (MDH) in soybean seeds, noted that the main differences were found with the advancement of the storage period at six and eight months and that in these storage periods the seeds stored in cold chamber had higher 
MDH activity compared to the ones stored in conventional warehouse, due to the higher stress suffered in uncontrolled conditions, particularly at eight months of storage. Vieira et al. (2013) found decreased activity of MDH, from six months of storage at $10{ }^{\circ} \mathrm{C}$ and $25^{\circ} \mathrm{C}$, but with greater effect at nine and twelve months of storage at $25^{\circ} \mathrm{C}$.

The highest expression of MDH enzyme in seeds harvested at $45 \%$ water content can be related to the physiological quality, since this fact is directly related to the incidence of mechanical damage, which was higher in these seeds. This fact is due to the damage to mitochondrial membranes, and this organelle is the one that is more susceptible to peroxidation. The increased activity may have occurred because of increased respiration in the seeds that were in the deteriorating process, since the enzymes involved in respiration can be activated in lower quality seeds (Tunes et al., 2014).

With respect to $\alpha$-amylase, lower expression was observed in seeds harvested at $45 \%$ moisture content in both hybrids studied (Figure 7). The development of $\alpha$-amylase activity is an important event that can be detected during early seed germination, and its main role is to provide substrates for seedling use until it becomes photosynthetically selfsufficient (Caixeta et al., 2014).

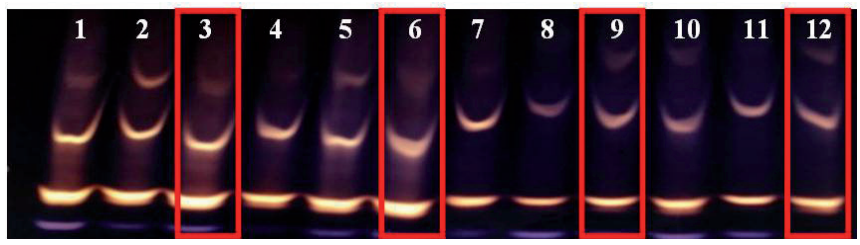

Figure 7. Enzymatic patterns of maize seeds harvested with different moisture contents (45\%, 40\% and 35\%) treated (T) and untreated (UT). Hybrid $1-\mathrm{BM}$ $810(1-45 \%$ T, $2-40 \%$ T, $3-35 \%$ T, $4-45 \%$ UT, $5-40 \%$ UT and $6-35 \%$ UT); Hybrid 2- BM $3061(7-45 \%$ T, $8-40 \%$ T, $9-35 \%$ T, $10-45 \%$ UT, $11-40 \%$ UT and $12-35 \%$ UT), disclosed for $\alpha$-amylase.

Seeds harvested at 35\% moisture content showed higher enzyme activity, because as the seeds lose water during the maturation process, they gain greater tolerance to desiccation and thus become tolerant to high drying temperature, which, according to Rosa et al. (2005), makes these seeds present a higher synthesis of the $\alpha$-amylase enzyme than intolerant seeds.

\section{Conclusions}

The isoenzymes expression varies according to the hybrid and the seeds quality.

There is an increase in the activity of $\alpha$-amylase and peroxidase enzymes, and decreased activity of enzymes superoxide dismutase (SOD), catalase (CAT), esterase (EST), alcohol dehydrogenase (ADH) and malate dehydrogenase $(\mathrm{MDH})$ as the seeds water content at harvest is reduced.

Seeds treatment does not interfere with the isoenzymes expression.

\section{References}

ALFENAS, A.C. Eletroforese e marcadores bioquímicos em plantas e microorganismos. Viçosa, MG: UFV, 2006. 627 p.

BRASIL. Ministério da Agricultura, Pecuária e Abastecimento. Regras para análise de sementes. Ministério da Agricultura, Pecuária e Abastecimento. Secretaria de Defesa Agropecuária. Brasília: MAPA/ACS, 2009. 395 p. http:// www.agricultura.gov.br/arq_editor/file/2946_regras_analise_sementes.pdf

CAIXETA, F.; VON PINHO, E.V.R; GUIMARÃES, R.M; PEREIRA, P.H.A.R.; CATÃO, H.C.R.M.; CLEMENTE, A.C.S.. Determinação do ponto de colheita na produção de sementes de pimenta malagueta e alterações bioquímicas durante o armazenamento e a germinação. Científica, v.42, n.2, p.187-197, 2014. http:// www.cientifica.org.br/index.php/cientifica/article/view/537

CARVALHO, E.R.; MAVAIEIE, D.P.R.; OLIVEIRA, J.A.; CARVALHO, M.V.; VIEIRA, A.R. Alterações isoenzimáticas em sementes de cultivares de soja em diferentes condições de armazenamento. Pesquisa Agropecuária Brasileira, v.49, n.1, p.967-976, 2014. http://www.scielo.br/pdf/pab/ v49n12/0100-204X-pab-49-12-00967.pdf

FERREIRA, D.F. Sisvar: a computer statistical analysis system. Ciência e Agrotecnologia, v.35, p.1039-1042, 2011. http:/www.scielo.br/pdf/cagro/ v35n6/a01v35n6.pdf

FERREIRA, V.F.; OLIVEIRA, J.A.; FERREIRA, T.F.; REIS, L.V.; ANDRADE, V.; COSTA-NETO, J. Quality of maize seeds harvested and husked at high moisture levels. Journal of Seed Science, v.35, n.3, p.276-277, 2013.http:/www.scielo.br/pdf/jss/v35n3/01.pdf

GALVÃO, J.C.C.; CONCEIÇÃO, P.M.; ARAÚJO, E.F.; KARSTEN, J.; FINGER, F.L. Alterações fisiológicas e enzimáticas em sementes de milho submetidas a diferentes épocas de colheita e métodos de debulha. Revista Brasileira de Milho e Sorgo, v.13, n.1, p.14-23, 2014.http://rbms.cnpms. embrapa.br/index.php/ojs/article/viewArticle/428

MAGUIRE, J.D. Speed of germination and in selection and evaluation for seedling emergence and vigor. Crop Science, v.2, n.2, p.176-177, 1962. https://dl.sciencesocieties.org/publications/cs/abstracts/2/2/CS0020020176

MARCOS-FILHO, J. Teste de envelhecimento acelerado. In KRZYZANOWSKI, F.C.; VIEIRA, R.D.; FRANÇA-NETO, J.B. (Eds.). Vigor de sementes: conceitos e testes. Londrina: ABRATES, cap.3, p.3.13.24, 1999.

MARCOS-FILHO, J. Fisiologia de sementes de plantas cultivadas Piracicaba: FEALQ, 2005. 495 p 
MARTINS, C.C.; NAKAGAWA, J.; RAMOS, P.R.R. Isoenzimas no monitoramento da deterioração de sementes de Euterpe espiritosantensis Fernandes. Revista Árvore, v.35, n.1, p.85-90, 2011. http://www.scielo.br/ pdf/rarv/v35n1/10.pdf

OLIVEIRA, J.A.; CARVALHO, M.L.M.; VIEIRA, M.G.G.C.; SILVA, E.A.A. Utilização de corantes na verificação de incidência de danos mecânicos em sementes de milho. Revista Brasileira de Sementes, v.20, n.2, p.125-128, 1998. http://www.abrates.org.br/revista/artigos/1998/v20n2/artigo21.pdf

ROSA, S.D.V.F., VON PINHO, E.V.R.; VIEIRA, E.S.; VEIGA, R.D.; VEIGA, A.D. Enzimas removedoras de radicais livres e proteínas lea associadas à tolerância de sementes de milho à alta temperatura de secagem. Revista Brasileira de Sementes, v.27, n.2, p.91-101, 2005. http://www.scielo. $\mathrm{br} / \mathrm{pdf} / \mathrm{rbs} / \mathrm{v} 27 \mathrm{n} 2 / \mathrm{a} 14 \mathrm{v} 27 \mathrm{n} 2 . \mathrm{pdf}$

TUNES, L.V.M.; FONSECA, D.A.R.; MENEGHELLO, G.E; REIS, B.B.; BRASIL, V.D.; RUFINO, C.A.; VILLELA, F.A. Qualidade fisiológica, sanitária e enzimática de sementes de arroz irrigado recobertas com silício. Revista Ceres, v.61, n.5, p.675-685, 2014. http://www.scielo.br/pdf/rceres/v61n5/11.pdf
VEIGA, A.D.; VON PINHO, E.V.R.; VEIGA, A.D.; PEREIRA, P.H.A.R.; OLIVEIRA, K.C.; VON PINHO, R.G. Influência do potássio e da calagem na composição química, qualidade fisiológica e na atividade enzimática de sementes de soja. Ciência e Agrotecnologia, v.34, p.953-960, 2010. http:// www.scielo.br/pdf/cagro/v34n4/v34n4a22.pdf

VIEIRA, B.G.T.L.; BARBOSA, G.F.; BARBOSA, R.M.; VIEIRA, R.D Structural changes in soybean seed coat due to harvest time and storage. Journal of Food, Agriculture and Environment, v.11, p.625-628, 2013. http:// www.world-food.net

VIEIRA, R.D.; KRZYZANOWSKI, F.C. Teste de condutividade elétrica In: KRZYANOWSKI, F.C.; VIEIRA, R.D.; FRANÇA-NETO, J.B. (Ed.) Vigor de sementes: conceitos e testes. Londrina: ABRATES, 1999. p. 1-26. PMid:10374823.

VIEIRA, M.G.G.C.; VON PINHO, E.V.R.; SALGADO, K.C.P.C. Técnicas moleculares em sementes. Informe Agropecuário, v. 27, n. 232, p. 88-96, 2006. 